\title{
Emotional Autonomy of Street Adolescence
}

\author{
Riza Noviana Khoirunnisa ${ }^{1, *}$ Nafila Ikrima ${ }^{1}$
}

\author{
${ }^{1}$ Department of Psychology Universitas Negeri Surabaya \\ ${ }^{*}$ Corresponding author. Email: rizakhoirunnisa@unesa.ac.id
}

\begin{abstract}
Street adolescences grow up in an unsafe environment, making them vulnerable to growing up with risky behaviours. However, if street adolescences have good emotional autonomy, they can control their emotions and behaviours. Good emotional autonomy is important to the adolescence for their next stage of development. The impact of low emotion autonomy can cause a bad emotional attitude, aggression, and inability to adapt to the new environment. This research aims to know the picture of emotional autonomy of street adolescences in Sidoarjo-East Java. This study used a survey method using subjects collected by purposive random sampling techniques with 60 subjects from 145 out of total street children in Sidoarjo. The data was collected using the scale of emotional autonomy, and the descriptive analysis was performed using Statistic Programs. The results showed that the emotional autonomy of street teenagers was in the moderate category. Age and family conditions are some of the factors that are quite influential to the emotional autonomy of street adolescences, but gender does not affect the level of emotional autonomy in street teenagers.
\end{abstract}

Keywords: Emotional Autonomy, Street Adolescence.

\section{INTRODUCTION}

Street teenagers spend their daily time on the streets to make a living. This street teenager works as a beggar, windshield cleaners, hawkers, buskers, shoe shiner, etc. Many teenagers living on the streets also come from different backgrounds, including poverty, victims of war, and other cases caused by parental divorce [1].

Data obtained from the Central Statistics Agency shows that Indonesia has a significant increase in street children every year, assuming an increase of $10.6 \%$ every year [2]. In Sidoarjo Regency, East Java, the number of street children is 145 street children of various ages [3].

Street children are a group of people who have a high risk and easy to mental health problems. Psychologically street children have a negative self-concept, dependence on others, are irritable, and have unstable emotions [4] The many impacts of deviant behaviour by street teenagers both from drug abuse and premarital free sex behaviour will cause problems, one of them is the danger of infectious diseases (HIV/AIDS) [5]. Also, another impact of premarital sexual behaviour is the existence of unwanted pregnancies caused by free sex, and an individual is not ready to become a mother so that the pregnancy will be aborted [6].

Immature emotional autonomy in street teenagers causes many problems. Emotional autonomy is how an individual does not depend on the emotional support of others, in this case, especially parents, in managing themselves [7]. When adolescences have been able to be good in emotional autonomy, then individuals have been able to develop aspects of value autonomy and behavioural autonomy so that adolescences can complete their developmental tasks well [7].

Preliminary studies were conducted on several street teenagers in Sidoarjo Regency; they said they had committed acts of violence to survive, difficulty regulating emotions, and dependence on peers. Street children are a group of people at high risk and vulnerable to mental health problems [4]. Vulnerable street teenagers have risky behaviours, and the impact of such behaviour is very dangerous for themselves and others [8].

Emotional autonomy is formed from several aspects and factors that affect it, aspects of emotional autonomy; according to [9], there are four aspects, two that are more relative to the cognitive component that is de-idealized and parent as people in general. The other two aspects are relatively more affective: non-dependency and individuation. De-idealize is about how teenagers view parents, not as ideal figures. In this aspect, teenagers begin to release the childish impression of being teenagers to their parents. Parents as people describe how a child views parents as adults in general. Non- 
dependency signifies a child's ability not to depend on parents in solving problems necessarily, and individuation is how the individual perceives himself and the progress of the individual experience developed by himself to be independent and responsible [10]. The emotional autonomy of adolescence is formed and developed due to several factors. There are internal and external factors that can affect emotional autonomy. Internal factors include age, birth order, gender, gender, and intelligence. At the same time, external factors are parental parenting, parental attachment, culture, education, and family economic status [11].

According to [7] and [12], several factors affect emotional autonomy; such factor is parenting because parents have a role in determining parenting style for children. An example is if parents establish authoritative parenting in adolescents, they can develop emotional autonomy; this is because this parenting type is good for developing confidence. After all, it allows opportunities for adolescences to make decisions. The attachment style of parents or caregivers becomes one of the important things in forming a child's emotional autonomy. Close relationships between parents and children will positively influence adolescent autonomy; attachment has an important role in helping children fulfil their developmental tasks, especially in achieving autonomy [12]. Peers also influence the emotional quality of individuals, wherein some studies it is said that an individual who is unable to regulate aggressive actions due to social competence with his peers during school; The last is ethnic culture.

This study aims to find out the picture of the emotional autonomy of street teenagers in the SidoarjoEast Java area. Based on various phenomena that have been described, it can be concluded that low emotional autonomy can have an impact on emotional attitudes, aggression, and not being able to adapt to environmental circumstances. This research is one of the first steps to uncover the profile of emotional autonomy in street teenagers.

\section{METHODS}

This research is a type of survey research. Survey research is a form of quantitative research that can determine the opinions, beliefs, or characteristics of a population [13]. The study was conducted in the Sidoarjo district, with 145 street children of various ages. While sampling is done by proportion sampling. Characteristics of the sample that researchers will take for research have characteristics that are by the research objectives, namely teenagers who live or work on the streets and aged 12-18 years, a total of 60 street teenagers.

The data retrieval technique used in this research uses a questionnaire method or a questionnaire containing several lists of statements in which respondents are asked to choose one alternative answer. The questionnaire was used to measure the emotional autonomy of the respondents.

The scale instrument in this study refers to the theory of Emotional Autonomy by Steinberg [9]. The instrument used in this study was made using a Likert scale. The Likert scale measures attitudes, opinions, and perceptions of a person or group towards a social phenomenon [14]. This scale is divided into two types, namely clear statements (F) and unfavourable statements (UF). The measuring scale used is the emotional autonomy scale.

In this study, the validity test used is using content validity which is the validity that is carried out through testing the test content with rational analysis and the extent to which the test items represent the components in the overall content of the object to be measured and the extent to which the test items reflect behavioural characteristics to be measured. The items in this study are valid if they have an item score of more than 0.3 [14]. Based on the results of trials on a scale that has been made on 30 respondents, the emotional autonomy scale has 32 valid statements and can be used to collect data.

According to [14], reliable research results are indicated by data similarity at different times. The reliability coefficient ranges from 0 to 1.00 , so the instrument is very reliable if the reliability results are close to 1 . The higher the reliability coefficient is close to 1.00 , the higher the reliability [15]. The emotional autonomy scale in this study obtained a reliability value with Alpha Cronbach is 0.959.

The data analysis in this study used descriptive statistics using the percentage of subjects (mean and standard deviation) with SPSS 25.0 software for windows so that it could classify the emotional autonomy of street teenagers who were high, medium, and low

\section{RESULTS AND DISCUSSION}

This study aims to find out the picture of emotional autonomy in street teenagers. The emotional autonomy scale has 32 valid statements and can be used to retrieve data. The highest score on the scale is five, and the lowest score is one. Here are the results of descriptive statistical calculations from the scale of the research data:

Table 1. Descriptive statistical test results

\begin{tabular}{|c|c|c|c|c|c|}
\hline & $N$ & Mean & $\begin{array}{c}\text { St. } \\
\text { Deviation }\end{array}$ & Min & Max \\
\hline $\begin{array}{c}\text { Emotional } \\
\text { Autonomy }\end{array}$ & 60 & 109.18 & 17.915 & 66 & 144 \\
\hline
\end{tabular}

Based on the data collection results, the highest score was obtained on the emotional autonomy scale of the study subjects of 144 . The lowest score obtained by the 
study subjects was 66. The results of descriptive statistical analysis obtained a mean value of 109.18 and a standard deviation of 17,915 .

Table 2. Test results of each aspect

\begin{tabular}{|l|c|}
\hline \multicolumn{1}{|c|}{ Aspect } & Mean \\
\hline De-idealized & 26,7 \\
\hline Parents as people & 18 \\
\hline Non-dependency & 32,6 \\
\hline Individuation & 27,9 \\
\hline
\end{tabular}

There are four aspects of emotional autonomy. De idealized aspects had an average of 26.7, parent as people aspect values of 18 , Non-dependency aspects of 32.6, and individualization aspects had an average of 27.9. Based on the average value of the above aspects, it is known that the aspect that most affects the emotional autonomy of street teenagers is Non-dependency, while the parent as people aspect is the least influential aspect in the emotional autonomy of street teenagers.

Table 3. Categorization of street adolescence emotional autonomy

\begin{tabular}{|c|c|c|}
\hline Tingkat & Frequency & Presents \\
\hline Low & 10 & $16,7 \%$ \\
\hline Moderate & 38 & $63.3 \%$ \\
\hline High & 12 & $20 \%$ \\
\hline Total & 60 & $100 \%$ \\
\hline
\end{tabular}

Based on the table above, the study results are categorized as moderate, with 38 street teenagers or $63.3 \%$ of the overall study subjects. 12 street teenagers, or $20 \%$, fall into the high category and 10 street teenagers or $16.7 \%$ fall into the low category.

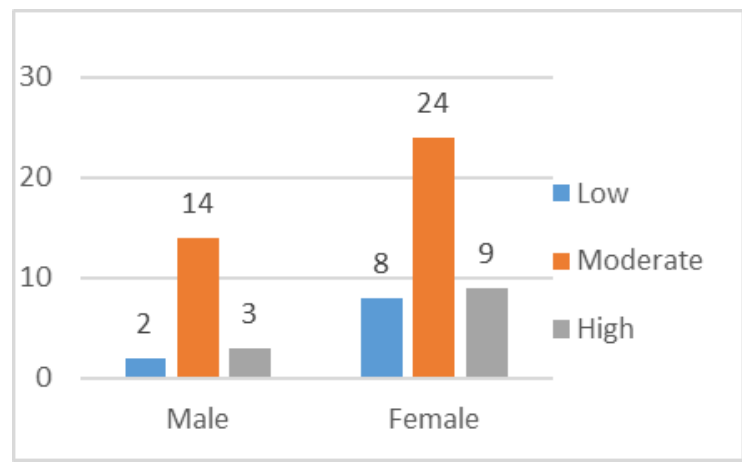

Figure 1 Results of emotional independence of street teenagers (based on gender)

Based on gender variation, $68.3 \%$ were female street adolescence, and $31.7 \%$ were male street teenagers, and both men and women were equally in the moderate category. Female street adolescences have greater emotional independence in the high category, which is $15 \%$, while there are only $5 \%$ of street boys.

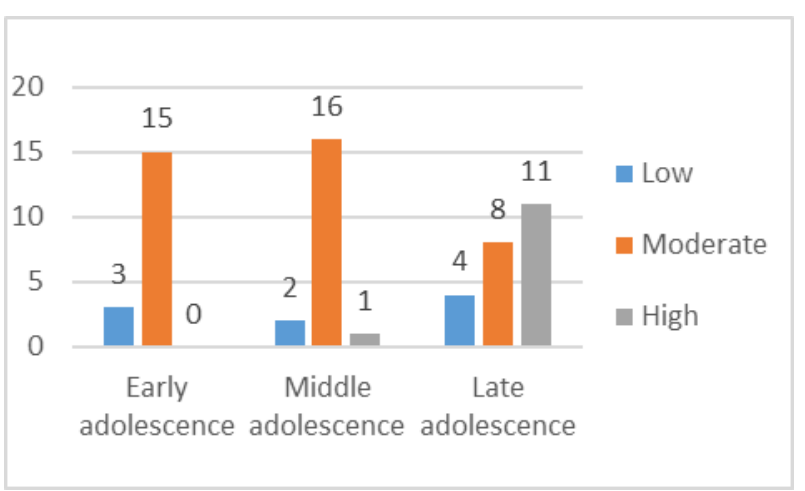

Figure 2 Results of emotional independence of street teenagers (based on age range)

Based on age, $38.3 \%$ were in the late adolescence stage, $31.7 \%$ were in the middle adolescence stage, and $30.1 \%$ were in the early adolescence stage. Most street children have a moderate category of emotional independence from the early and middle adolescence age range, while subjects tend to have high autonomy in the late adolescent range.

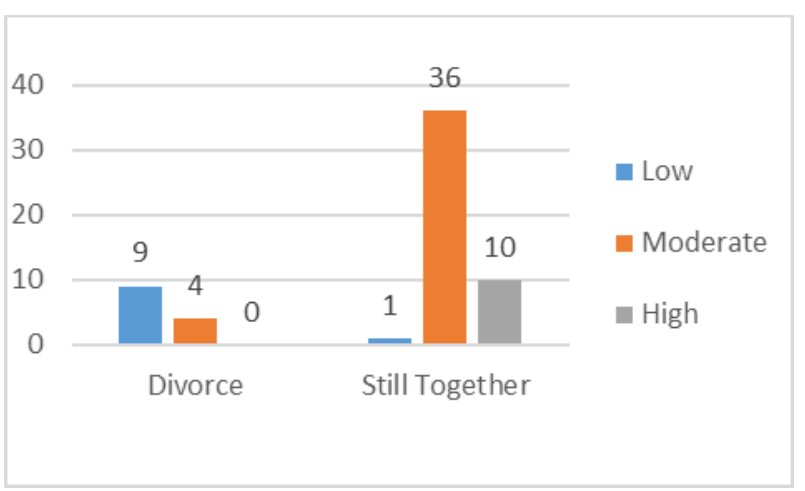

Figure 3 Results of emotional independence of street teenagers (based on family condition)

Based on family conditions, the status of divorced parents by $22 \%$ and parents who are still together by $78 \%$. Street teens with divorced parents had a low emotional autonomy category of $96.2 \%$, and street teens with parents who were still together were in the category of moderate emotional independence at $76.6 \%$.

Adolescence is a period of growth into adulthood where individual changes from the immaturity of childhood to the stage of maturity in adulthood, in preparation for the future. Changes that individuals experience in adolescence include biological, social, and cognitive changes so that with these changes, individuals are expected to understand the tasks of adolescent development so that individuals can reach maturity in adulthood later.

In early adolescence, the first developmental task is emotional autonomy, which is a change in the attachment of an individual's relationship with parents emotionally 
[10]. Adolescents are no longer interested in doing activities with parents, do not want to listen to advice or criticism from parents, and emotional bonds with parents are no longer as close as when children [16].

Great emotional independence is important for adolescents for developmental maturity at a later stage. The level of emotional independence of street teenagers is in the moderate category. This is because increased emotional autonomy is not as fast as increased behavioural autonomy [17]. The achievement of the level of emotional autonomy that street children also cause tends to be far from their parents from an early age, their parenting style, and relationships with comparable figures who require them to be more independent than the children in their age and the environment [18].

Emotional autonomy in street teenagers has four basic aspects: de idealized, parent as people, non-dependency, and individuation. The dominant aspect that causes emotional autonomy to appear in street adolescence is non-dependency. In the non-dependency aspect, street adolescence depends on their abilities, not expecting parental help. This can be seen from the behaviour of street teenagers in the ability to delay the desire to immediately express feelings to parents and delay the desire to ask for help from parents or other adults when they have problems. According to [19], teenagers depend on themselves rather than their parents for help. Adolescents have a level of ability to learn more on their strengths than on relying on parents. The second aspect that influences the emotional autonomy of street teenagers is individuation. According to [19], individuation is emotional independence in adolescents with a degree of individuation in relationships with parents. Individuation means behaving more responsibly. The behaviour of individuation that can be seen is seeing the difference between the view of the parent and his view of himself and showing more responsible behaviour. Individuation in adolescents about their relationship with parents where they feel they have a personal life that parents do not always know. The third aspect that affects emotional autonomy is de-idealized. Teenagers understand that parents do not always know, are always right, and have power, so that when they decide something, they no longer rely on their parents' emotional support. According to [19], de-idealized is the ability of adolescents not to think of parents as ideal and perfect in the sense that their parents are not always right in determining attitudes and policies. The last aspect that affects street teenagers in emotional independence is a parent as people. Adolescents see parents as individuals other than as parents and interact with parents in parentchild relationships and relationships between individuals. According to [19], perceived parents as people is the ability of adolescents to look at parents like other people in general.
Teenage boys and teenage girls have emotional independence at the same level. However, teenage boys become more independent than girls [16]. Emotional independence in adolescents does not mean their rebellion against the family or releasing a parent's relationship with the child. Achieving emotional independence is not damaging or severing family relationships. Blos [20] suggested that the development of emotional autonomy begins with the individuation of the parents and ends with the achievement of identity, as Erickson said.

Street teenagers who have divorced parents have low levels of emotional autonomy. Divorce will cause stress in teenagers, so it can cause teenagers to experience anxiety and depression because of it [21]. Booth [22] pointed out that individuals with divorced parents at an early age show low psychological well-being when the individual becomes an adult, compared to individuals whose parents are not divorced. [23] reveals that an individual's experiences in early childhood will create an internal working model as an individual's foundation is looking at his or her world, others, himself, even about his future relationships.

Street teenager in the Late adolescent category is in the high category. Street teenagers in the range of early and middle teens are at a moderate level of emotional autonomy. This is because when entering adolescence period the demands for emotional independence become greater so that if a teenager grows up without good emotional autonomy, it will have a bad impact on the psychological development of adolescents in the future. For example, children will depend on their parents, be unable to make good decisions about themselves and others, and distrust the environment and others. It is feared that it will cause street teenagers close to violence, casual sex, and drugs. Therefore, parents are expected to provide opportunities for children to be able to develop their independence, such as taking the initiative, making decisions, and being responsible for their actions. If the attachment development is by their age, emotional autonomy can be well achieved [24].

Adolescents who live separately from their parents will develop more independently than adolescents who still live with their parents [16]. Emotional independence is also seen from the pattern of control and warmth that parents give to adolescents [16]. As emotional independence develops, street teenagers consider parents as adults in general. Children no longer rely on parents in solving problems. In this study, it is known that street teenagers prefer to solve their problems or ask for the help of friends; when teenagers begin to enter adulthood, they will feel increasingly embarrassed and avoid their parents. As teenagers, they begin to be separated from their parents and are often closer to figures after parents or other than their caregivers [25]. These figures include teachers, upperclassmen, school friends, or their peers. 


\section{CONCLUSION}

Based on the results of this study, it can be concluded that the emotional independence of street teenagers shows at in moderate level. Emotional autonomy has four base aspects: de-idealized, parents as people, nondependency, and individuation. Among the four aspects, non-dependence is the dominant behaviour that underlies emotional independence in street youth. Emotional autonomy in street adolescents indicates a relationship with gender, adolescent age range, and parental status.

There is still little research done on street teenagers, so it is expected that this study can be developed with other variables. Street teenagers are advised to follow education and attend associations provided by the government in the development of street children or programs held by educational organizations caring for street children to be more able to understand their abilities and become a benefit. Parents are expected to learn and understand the child's developmental process, especially when stepping on in adolescence. Maintain communication with adolescents and provide education to adolescents in building relationships and communitarians with their environment.

\section{REFERENCES}

[1] Aisyaroh, Fitria. "Kemandirian Anak Jalanan Dalam Perspektif Pendidikan Kritis Di Yayasan Alit Surabaya." J+ Plus Unesa 7, no. 3 (2018).

[2] Purnomo, Moh Abdul. "Peran pekerja sosial dalam meningkatkan kemandirian anak jalanan melalui pelatihan melukis di UPTD kampung anak negeri wonorejo Surabaya." J+ Plus Unesa 6, no. 2 (2017).

[3] BPS. Penyandang Masalah Kesejahteraan Sosial Menurut Kabupaten/Kota di Provinsi Jawa Timur. https://jatim.bps.go.id/statictable/2019/10/16/2044/ penyandang-masalah-kesejahteraan-sosialmenurut-kabupaten-kota-di-provinsi-jawa-timur2017.html (2017)

[4] KEMENKES RI. Riset Kesehatan Dasar (RISKESDAS). KEMENKES RI. www.litbang.depkes.go.id (2013)

[5] BKKBN. Laporan pendahuluan remaja SDKI 2012. BKKBN. www.bkkbn.go.id (2012)

[6] Banun, Fadila OS, and Soedijono Setyorogo. "Faktor-faktor yang berhubungan dengan perilaku seksual pranikah pada mahasiswa semester V STIKes X Jakarta Timur 2012." Jurnal Ilmiah Kesehatan 5, no. 1 (2013): 12-19.

[7] Steinberg, L. Adolescence In McGraw-Hill (11th ed.). McGraw-Hill. (2016)
[8] Lubis, E. D. T., \& Hayati, H. Kematangan emosional anak jalanan usia remaja di wilayah jakarta. FK UI, 1 (2016): 1-11.

[9] Steinberg, L., \& Silverberg, S. B. The vicissitudes of autonomy in early adolescence. Child Development, 57(4) (1986): 841-851. https://doi.org/10.1111/j.14678624.1986.tb00250.x

[10] Steinberg. Adolescence (10th ed.). McGraw Hill. (2014)

[11] Diazforawati, N. P. Perbedaan Kemandirian Emosional Ditinjau Dari Jenis Kelamin Pada Mahasiswa Perantau Universitas Kristen Satya Wacana [Universitas Kristen Satya Wacana]. In Universitas Kristen Satya Wacana. (2015) https://doi.org/10.1145/3132847.3132886

[12] Santrock, J. W. Life Span Development. McGrawHill. (2011)

[13] Creswell, John W., and Cheryl N. Poth. Qualitative inquiry and research design: Choosing among five approaches. Sage publications, 2016.

[14] Dr, P. "Sugiyono, Metode Penelitian Kuantitatif Kualitatif dan R\&D." CV. Alfabeta, Bandung (2008).

[15] Azwar, Saifuddin. "Reliabilitas dan validitas." Yogyakarta: pustaka pelajar (2012).

[16] Santrock, John W. Adolescencia. AMGH Editora, 2014.

[17] Fleming, Manuela. "Adolescent Autonomy: Desire, Achievement and Disobeying Parents between Early and Late Adolescence." Australian Journal of Educational \& Developmental Psychology 5 (2005): 1-16.

[18] Syarif, Nuril Rifanda Handayani. "Pengaruh kelekatan (attachment) terhadap kemandirian emosi pada mahasiswa perantauan Maluku Utara yang kuliah di Malang." PhD diss., Universitas Islam Negeri Maulana Malik Ibrahim, 2017.

[19] Steinberg, L. Adolescence (6th ed.). McGraw Hill, 2002

[20] Spencer, M. B., W. Damon, and R. Lerner. "Child and adolescent development: An advanced course." (2008): 696

[21] Størksen, Ingunn, Espen Røysamb, Turid L. Holmen, and Kristian Tambs. "Adolescent adjustment and well - being: effects of parental divorce and distress." Scandinavian journal of psychology 47, no. 1 (2006): 75-84. 
[22] Puspitasari, Putri, Sri Maslihah, and Anastasia Wulandari. "Pengaruh Kelekatan Terhadap Kesejahteraan Psikologis Yang Dimediasi Oleh Resiliensi Pada Remaja Dengan Orang Tua Bercerai." Jurnal Psikologi Insight 4, no. 1 (2020): $32-44$.

[23] Bowlby, John. "Attachment theory, separation anxiety, and mourning." American handbook of psychiatry 6 (1975): 292-309.

[24] Fadhillah, Nurul, and Syarifah Faradina. "Hubungan kelekatan orangtua dengan kemandirian remaja SMA Di Banda Aceh." Jurnal Ilmiah Mahasiswa Psikologi 1, no. 4 (2016).

[25] Armsden, Gay C., and Mark T. Greenberg. "The inventory of parent and peer attachment: Individual differences and their relationship to psychological well-being in adolescence." Journal of youth and adolescence 16, no. 5 (1987): 427-454. 